\title{
Weddings and white dresses: Media and sexual citizenship in Japan
}

Claire Maree, Asia Institute, University of Melbourne, Australia

\section{Abstract}

Representations of gender and sexuality in mainstream media operate to both shape the contours of, and contest the limits to, sexual citizenship. The 'citational practices' of media representations mould contemporary understandings of these limits. In this article I examine mainstream and social media reports of two separate same-sex wedding ceremonies in Japan; the first at a queer community event in 2007 and the second at a major theme park in 2013. Through citations and quotations, a multitude of voices are embedded in the media texts. In the 2007 case, increased media visibility is mitigated by citational practices that clearly mark the same-sex wedding as devoid of legal standing. Whereas media reports situate the 2013 ceremony in the context of marriage equality trends internationally, an instance of possible discrimination is emphasised as being a 'misunderstanding'. Similarly, a microanalysis of a light news documentary of the ceremony uncovers citational practices that highlight the importance of 'forgiveness' or 'tolerance' for 'mutual coexistence' in society. Furthermore, the reporting confines the ceremony to a 'fairytale'-like 'foreign' domain. The process of 'othering' issues of sexual citizenship is linked to a cyclical process since the 1950s wherein representations of queerness are posited as 'new' forms of being in Japan. Discourse surrounding sexual citizenship is thereby projected into a non-domestic, non-specific future time. 


\section{Keywords}

sexual citizenship, Japan, media discourses, citational practices, social media, tolerance

Corresponding Author: Claire Maree, Asia Institute, Sidney Myer Asia Centre, University of Melbourne, 3010, Victoria, Australia.

Email: cmaree@unimelb.edu.au

\section{Introduction}

Popular culture and the media are increasingly being studied alongside legal and social discourses of sexual rights within sexual citizenship scholarship (Cossman, 2007; Kachgal, 2004; Porfido, 2009; Seidman 2001). Analysis of popular media highlights the intersections of gender and sexuality in the processes and modes of inclusion and belonging that are central to notions of sexual citizenship. Cossman argues, for example, that 'practices of belonging and, particularly, the sexing, privatizing, and selfdisciplining of these practices are products of the porous borders between law and popular culture' (Cossman, 2007: 18). Cossman's turn to media analysis, however, is not without critique. In their review essay of Cossman's Sexual Citizens (2007), Robson and Kessler maintain that the "construct of "sexual citizenship" needs to be grounded', specifically 'in the legal consequences of sexual minorities' access and denial of access to citizenship' (2008: 539). In particular, they ask, how can audiovisual media such as film be imagined as constituting citizenship when consumers who view it are situated in diverse geographical locations (554), and may not be affiliated with the same nationstate?

Analysis of cultural modes of sexual citizenship constituted through international media 
flows could be envisioned as removed from questions of legal citizenship because citizenship is tied to mutually shared geospatial points of belonging. However, as Kahlina's work on sexual citizenship in post-Yugoslav Croatia and Serbia clearly shows, 'global and local constellations' must be examined fully when analyzing discourses of sexual equality (2015: 73-74). Furthermore, as scholarship in critical discourse analysis consistently demonstrates, popular culture, politics and media are interdependent (Wodak, 2010: 44). It is precisely because media circulates in increasingly global ways that it remains salient to discussions of sexual citizenship in the contemporary moment. In this article, therefore, I take the view that representations of gender and sexuality in mainstream media operate to both shape the contours of, and contest the limits to, sexual citizenship in tangible ways. Furthermore I propose that analyzing the citational practices of media discourse surrounding issues at the core of sexual citizenship enables us to examine what is transported and how this affects the parameters of sexual citizenship as defined within local contexts. I will examine how citational practices in reports on same-sex weddings operate to manipulate discourses regarding the legitimacy of claims for the right to same-sex marriage and/or partnership rights in Japan. These claims are part of the 'relationship-based cluster' of sexual rights outlined by Richardson (2000: 108, 123-127). They also intersect with the 'identitybased cluster' which encompasses the right to self-determination, and the right to pursue a lifestyle through consumption of goods and services (Richardson 2000: 116$123)$.

The words and thoughts of individuals, corporations and institutions are embedded (Goffman, 1981: 3) in media texts through complex 'citational practices' (Goodman et al., 2014). Citation is an act where meaning is transported from one context to another. 
Language thus embedded can be manipulated to support or contest arguments for which social, political and/or civil rights and responsibilities should be afforded to the individual according to their gender and/or sexuality. Citation is a process of recontextualization. It is dialogical in the Bakhtinian sense. All utterances are linked 'in a very complexly organized chain of other utterances' (Bakhtin, 1986: 69) which respond not only to those which have come before them, but also those which will follow. In media reports, the utterances of spokespeople or the language of legal documents embedded in news reports are used 'to convey and serve the purpose of the writer' (Calsamiglia and Ferrero, 2003: 149). Citational practices are abundant in social media as well. The 'shared' and/or 'liked' news and views of microblogs, audiovisual media clips, memes and other digital texts also produce a chain of citations. Information and opinions are shared, reported and re-voiced in relation to the 'metapragmatic, sociocultural, ideological and institutional dimensions' (Goodman 2014: 450) of the media into which they are embedded.

Below, I examine two same-sex wedding ceremonies that have attracted mainstream media attention in Japan. The first wedding ceremony is between politician Otsuji ${ }^{\mathrm{i}}$ Kanako $^{\text {ii }}$ and her partner Kimura Maki. It was held during the NLGR (the event is known for this acronym which stands for Nagoya Lesbian and Gay Revolution) in March 2007. The second is a wedding ceremony between Higashi Koyuki iii and her partner Hiroko $^{\text {iv }}$ (who is referred to in media reports about the ceremony at the time by her given name only). ${ }^{\mathrm{v}}$ It was held in 2013 at Tokyo Disney Resort. Separated by six years, both wedding ceremonies are situated in differing socio-political contexts. A major contextual point for the 2007 ceremony is the House of Councillors election. The Tokyo Disney Resort ceremony, however, is framed by social-media advocacy, calls for 
equal rights to consumption, and international calls for marriage equality. Both events are connected to the wider socio-political issue of same-sex marriage, and draw on a history of activism and discussion surrounding same-sex partnership rights. Reporting on both the ceremonies involves multiple layers of citation. In this 'intertextual chain or network of texts and events' (Fairclough et al., 2010, 420), some claims are emphasized and others mitigated by the use of embedded language. To contextualize this discussion, however, it is first necessary to briefly outline media representations of LGBT issues in Japan, and the current state of legal marriage in Japan.

\section{Queer(y)ing Japanese Media}

In Japan, there is relatively high visibility of queer personalities in popular culture; gender reassignment is available; and there have been legal amendments to allow individuals to alter the sex appointed to them at birth on legal documents. ${ }^{\text {vi }}$ Some might interpret this as evidence of a queer-friendly outlook in Japanese society. Researchers and social commentators alike, however, have noted a gap between media representation and full access to legal and sociocultural institutions. In a February 2012 article, Doi Kanae, of Human Rights Watch, urged the major national daily newspaper Asahi Shimbun to be more proactive in publishing about LGBT issues (Doi, 2012: 14). In this contribution to the 'My Newspaper critique' series, penned by members of the Asahi Shimbun's Press Advisory Council, Doi notes that, despite an abundance of queer-queen $(o n \bar{e})$ personalities ${ }^{\mathrm{vii}}$ in the popular media, in the previous two years only one report—about the Aomori LGBT Film Festival—published in the paper had contained the acronym LGBT. Widening the search to include the terms 'homosexual' (dōseiai-sha) or 'GID' (Gender Identity Disorder/seidōitsusei shōgai) produced few other hits. Doi finishes her critique by urging the paper to act on its reputation as an 
opinion leader and increase meaningful coverage of LGBT issues, thereby contributing to public discourse surrounding LGBT human rights, discrimination, same-sex marriage and gender reassignment conditions for transgendered people; all of which fall under the rubric of sexual citizenship.

Doi's article points to a fissure between visions of excess. Although there has been a marked increase in use of the LGBT acronym coverage of same-sex marriage since 2012, the excessive use of MTF and/or queer one-kyara in popular mainstream media outweighs reporting of socio-political LGBT issues and associated commentary. Doi's observation resonates with research on media representations of homosexuality, queerness or LGBT peoples and issues (Chalmers, 2001; Ishida and Murakami, 2006; Maree 2013, 2014; Sugiura, 2006: 127-144). From the 1950s to the present, there have been constant shifts in the terminology used to refer to gender variant individuals or sexual minorities within mainstream media. The idea of 'newness' is repeated as images of LGBT peoples are cyclically reiterated in mainstream media and 'new' nomenclature is applied to each successive image. This tendency to situate as 'new' alternative genders and sexualities is also noted in the citational chains undercutting media representations of same-sex marriage in Japan which avoid linking histories of activism to current discussions in contemporary reports. Let us now turn to an overview of legal marriage in Japan, before analysing media reports on the same-sex wedding ceremonies.

\section{Legal Marriage in Japan-a brief overview}

Reference to marriages between individuals of the same sex/gender, can be found in mainstream newspapers as far back as the late nineteenth century. The collected volume 
of Asahi Newspaper articles relating to love and marriage contains a report from 1899

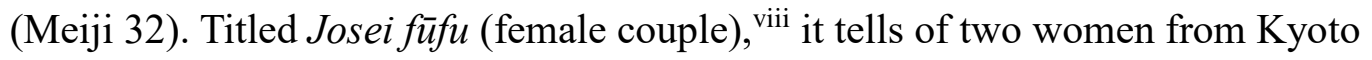
entering into a husband and wife contract that included a clause stating that a fine would be payable if either party entered into a contract with another man or woman (Asahi Shimbunsha, 1997: 141). The 27 January 1910 edition of the Yomiuri Newspaper contains the article Onna dōshi no füfu (a female couple) which recounts the story of two women who left their husbands to live together, only to eventually break up when one of the women decided that 'a man was better for a husband' (Yomiuri Shimbun, 1910: 3). In both of these articles, the relationship is framed as spousal with the use of the word $f \bar{u} f u$-literally 'husband and wife'. The notion of $f \bar{u} f u$ ('husband and wife') is central to contemporary understandings of marriage in Japan.

With the promulgation of the Constitution of Japan in 1946 (effective 1947), marriage was legally defined in Article 24 as being entered into according to the free will of both sexes (kekkon wa, ryōsei no gōi nomi ni motozuite seiritsu). The Civil Code was also revised in 1947 to define marriage in more egalitarian, if heterocentric, terms. Partners register their application to marry at their local government office as 'the one who will be husband' and the 'one who will be wife'. Once registered, the partners take up the position of husband and/or wife on a family register $(\text { koseki })^{\mathrm{ix}}$ wherein they must share the family name of the head or primary registrant (hittōsha). The primary registrant (hittōsha) may be either the husband or wife, but it is more common for the couple to adopt the man's family name. Lobbying for the right for legally married couples to maintain distinct family names has not been successful to date. ${ }^{\mathrm{x}}$

Couples in female/male de facto relationships have been successful in attaining some of the rights a legally married couple can claim. They have access to the national pension 
scheme, public housing, and compensation in case of an untimely death. Female/male de facto couples, however, cannot be registered as joint parents of children born between them, neither can they adopt because they do not occupy the same family register. Female/male de facto relationships are not recognised under immigration laws. There are no rights to inheritance outside of the family registration system and legal family members can claim full legal entitlement to property even when a will with the de facto partner as beneficiary has been registered as a notary deed. It is within this context that same-sex couples have embarked on various strategies. They have made legal familial relationships through adult adoptions, ${ }^{x i}$ drawn up partnership agreements and registered these as notary deeds; and conducted wedding and commitment ceremonies. Most recently, several municipal governments have introduced certificates for same-sex partners that give limited local recognition to them as partners. ${ }^{\text {xii }}$

LBGT community activism around partnerships and family became prominent from the late-1980s 'gay boom'. xiii Increased media attention included an interest in partnership rights. For example, publications of first-hand accounts of same-sex partnerships (Ito, 1993; Izumo, 1993; Izumo and Maree, 2000; Ōtsuka, 1995), community based activism, and columns and articles in community press publications (see, for example the 'Marriage Law/Domestic Partnerships' section of articles in the 1996 edition of the journal Queer Studies [Queer Studies Henshūiin-kai, 1996]). Press generated by mainstream publications also referenced partnership rights. The April 1997 edition of Cosmopolitan Japan contains an interview with Izumo and Maree, which focuses on the joint-living agreement registered as a notary deed (kōsei shōsho) intended to set out the couple's rights and responsibilities over and above the legal limits of the family registry system (Hosogai, 1997: 106-109). In a period of well-documented declining birth rates 
and marriage rates, alternatives to the discriminatory nature of the family registry system, such as joint-partnership agreements and lobbying for alternative de facto marriage rights regardless of the partner's gender and or sexuality gradually became a nexus for debate and discussion. Community level wedding ceremonies without any legal standing also began to gain in visibility. One such ceremony that garnered the interest of the mainstream media was between Otsuji Kanako and her partner in 2007.

\section{Mitigation and support—citation marks at work}

In June, 2007 Otsuji Kanako and her partner Kimura Maki held a public wedding ceremony in Nagoya as part of NLGR (as noted above, the event is known for this acronym which stands for Nagoya Lesbian and Gay Revolution). Otsuji, a member of the Osaka Prefectural Assembly from 2003 to 2007 and member of the House of Councillors of the National Diet of Japan (May 2013-July 2013), ${ }^{\text {xiv }}$ is well-known as the first openly lesbian politician at the local and/or national level. She published her autiobography Coming Out in 2005 (Otsuji 2005) and was featured on the cover of the 'Gay in Japan' issue of News Week Japan (25 January 2006) the following year. News of her planned wedding was revealed at the news conference announcing her standing for election to the House of Councillors. The wedding ceremony was held just before the historic 2007 election. Although The Democratic Party of Japan (DPJ) was successful in gaining a majority over the Liberal Democratic Party (LDP), Otsuji was unsuccessful in her bid for a seat.

In the coverage of Otsuji's wedding, we can see the beginnings of intersections between online and tradition print media. We can also observe the crossover to social media from more traditional forms of community organizing through mini-komi newsletters 
(short for mini komyuinikēshon [mini communication]) and print magazines. Footage of the wedding is available on YouTube, where copies of the press conference following the event can also be viewed. Although a search of online mainstream and tabloid press for articles about the event will no longer deliver hits, many articles from the time are archived in 'copy and paste' versions on blogs. Archival material in online LGBT newspapers and magazines also remains accessible; the archives of webzine Tokyo Wrestling have a report about the news conference where the wedding was announced (Keiser, 2007) and posts of the wedding itself appear in Gay Japan News (Yamashita, 2007), Pink News UK (2007) and Just Out (Wockner, 2007).

The domestic and international LGBT press report on the event with a celebratory tone. The mainstream Japanese press, however, are more cautious in their approach. The citational practices employed give an indication of the ideological subtext of the reports. The Nagoya edition of the Asahi newspaper carries a report with the title 'Two women together Promise everlasting love-_Wedding” in Naka-ku' (Asahi Shimbun, 2007: 30). ${ }^{\mathrm{xv}}$ It features a full body shot of the couple in white wedding dresses, firmly holding each other's hands and each clasping a bouquet with the other hand. The cleric who presided over the ceremony can be seen in the background. The article opens with the sentence 'Two brides in pure white wedding dresses go along the virgin road. ${ }^{\mathrm{xvi}} \mathrm{It}$ describes the event as an "unusual "wedding ceremony between women"' (Asahi Shimbun, 2007: 30). The curiousness of the affair is emphasized by encasing the phrase 'wedding ceremony' (kekkonshiki) in squared quotation marks. The use of quotation marks mitigates the meaning, emphasising that the ceremony is not 'real' in any legal sense. In Japanese, as in English, quotation marks may be used either to indicate a direct quote, or to indicate some distancing from the word or phrase encased. 
As well as noting the presence of family at the 'exchange of rings', the Asahi article mentions congratulatory telegrams sent 'by leading members of the same party such as then DPJ leader "Ozawa Ichirō" and [DPJ member] "Hatoyama Yukio"” (2007: 30). The names are also encased in quotation marks giving the impression that the telegrams are being directly cited. The citation of support from the DPJ leaders is an important background element of this story. A segment on Nippon Television Network (NTV)'s News Zero broadcast ${ }^{\mathrm{xvii}}$ of the election results covers Otsuji on her campaign trail. It includes scenes from the wedding, and Otsuji campaigning in Shinjuku Ni-chōme, one of Tokyo's most well-known LGBT entertainment districts. The faces of the women to whom Otsuji talks are blurred and their voices altered to protect their privacy. The words 'discrimination' (sabetsu) and 'prejudice' (henken) are projected onto the screen visually citing the narrator's explanation that many homosexuals (dōseiaisha) do not disclose their sexuality for fear of discrimination and prejudice. ${ }^{\text {xiii }}$ One woman says that even though she would like to, she is unable to marry her same-sex partner. Otsuji promises to work to change the laws. Scenes of the campaign include a recorded message from Ozawa Ichirō, head of the DPJ at the time of the 2007 elections. ${ }^{\text {xix }}$ Ozawa acknowledges the existence of 'many homosexual people' and notes the importance of the work Otsuji is doing. His speech is projected word for word onto the screen. This visual citation highlights the backing of the DPJ in raising visibility for LGBT peoples and their rights.

In sum, the media representations of Otsuji and her partner's wedding are firmly linked to domestic politics and the limitations of legal marriage in Japan through citational practices. The use of citation in the form of quoting from telegrams, splicing congratulatory messages into the news documentary and projecting selected sections of 
interviews and narration onto the screen as text, authenticates calls for greater attention to LGBT issues. However, the use of quotation marks within the newspaper reporting at the same time highlights the non-legal nature of a union between two women. Furthermore, the citation of selected words from the narration as text-on-screen and the need to hide interviewees' identities visually reinscribes issues of discrimination and prejudice. Hence, increased media visibility is mitigated by conflicting citational practices wherein the parameters of sexual citizenship are visually and linguistically clearly truncated.Both what is transported into the text through citational practices, and how it is transported, affects the parameters of sexual citizenship in this local context. Amessage of muted visibility is also underlined in reporting on the 2013 Tokyo Disney Resort wedding. In this instance calls by a same-sex couple to be allowed to enjoy a wedding ceremony package available to heterosexual couples provided impetus for a social media campaign of marriage equality and visibility rights which was then also reported by the mainstream press. Citational practices common to social-media communication such as 'sharing' and 'retweeting' are the catalyst for discussions on who should be permitted access to commercial wedding services.

\section{White wedding dress in a fantasyland}

In March 2012, Higashi Koyuki telephoned Tokyo Disney Resort to inquire about purchasing one of the new wedding services being offered. Packaged weddings in Japan are big business, and a Tokyo Disney Resort ${ }^{\mathrm{xx}}$ (hereafter TDR) package is just one of the many on offer for purchase. ${ }^{x x i}$ Once it became apparent that her partner was female, Koyuki was advised that a wedding ceremony would be possible only if one partner 'dressed as to appear male'. On questioning why, she quotes the following response: 'as 
you will be going not only into the hotel but into the park as well, it is difficult considering the effect it may have on general customers (ippan no okyakusama)' (Higashi, 2012a). When pressed to give further details on the possible detrimental effects, she was advised that her call would be returned. Koyuki relayed this interaction on her social media account spurring a chain of citations as the posting was 'retweeted' (via Twitter), 'shared' (onTumblr), 'liked' (via Facebook) and 'publically recommended' (on Google+). It quickly became an online discussion point. When Koyuki posted the official response from TDR which stated there had been 'incomplete/defective understanding within the company' (shanai no ninshiki ga fukanzen), the number of retweets peaked in the seven-thousands (Higashi, 2012b). In this instance the chain of interconnecting texts and citations begins within a telephone conversation recounted on social media, rather than beginning with a press conference, as was the case with the 2007 ceremony.

The story made its way into online news. Written in Japanese, a 15 May 2012 AFP-BB News report titled 'Same-sex wedding, backed by Mickey Mouse too, Tokyo Disney Resort' opens with the claim that US president Barack Obama's support for gaymarriage has been followed just days later with 'the appearance of a new supporter of same-sex marriage-Mickey Mouse' ( $A F P-B B$ News, 2012). For readers who had been following the events as reported in social media, this appeared to be a case of reversed chronology. Koyuki posted news of TDR's approval of a 'wedding dress x wedding dress' on 2 April 2012 (Higashi, 2012b). She also posted photos of the couple's May 5 visit to TDR to deliver 'thank you messages' to Mickey on 8 May 2012 (Higashi, 2012c). However, the article is actually referencing the words of a TDR representative: 
'A ceremony at the Cinderella Castle is also possible. Stated a PR representative of the same resort, on the 15th.' (AFP-BB News, 15 May 2012).

The chain of association that links TDR approval with the US president's support of same-sex marriage also works to situate the issue of marriage equality in a foreign, fairytale, Cinderella-like space. The invocation of the US seems to suggest that Japan is somehow lagging behind, and appeals to the rhetoric of gai'atsu, or the 'applying of pressure from abroad' as the only way to make for change within Japan.

The TDR public relations officer's explanation of the original condition being a misunderstanding on the part of a lone employee works to deflect any claims of corporate discrimination. This theme is continued in reports published after the event. For example, the New York Times 'Gay wedding is embraced by Disney in Tokyo' cites a Milial Resort Hotel spokesperson as stating it was 'an incomplete understanding on the part of our staff over the requirement for dresses' (Tabuchi, 2013). The spokesperson continues, '(i)f we caused them sadness and discomfort, we are sorry’ (Tabuchi, 2013). The phrase 'incomplete understanding' is quoted again here. It repeats in translation the words Koyuki used in her initial microblog and frames the issue as arising from a lack of information, rather than an intention to discriminate. This citation effectively depoliticizes the chain of events.

Although the issue of supposed discrimination is de-emphasized, the articles make full use of photos from the event that visualise the root of the initial 'incomplete understanding'. An Asahi article posted online titled 'Woman and woman, wedding ceremony in dresses. Wishes come true at Disney Sea' (Asahi Shimbun, 7 April 2013) features a photo of the couple in white wedding gowns, cutting the wedding cake. The 
act of cutting the wedding cake symbolises the first collaborative act in the newly-weds' lives. Just visible on the cake in this iconic shot are two small dolls dressed in identical gowns and veils, holding bouquets and smiling. The 5 March 2013 New York Times (Tabuchi, 2013) article discussed above also pictures the two women dressed in white gowns. They are holding a marriage certificate and are flanked by Mickey and Minnie Mouse, one on each side of the couple.

Reporting on the 2013 TDR wedding highlights the lack of legal status afforded to the women after taking part in the public wedding ceremony. An ITN online report notes that '(s)ame-sex couples are not legally recognised in the country, with gay couples not afforded hospital visitation rights, tax breaks, insurance or even protection from being discriminated against in housing and employment opportunities' (Foster, 2013). The New York Times invokes the image of the closet, claiming that even though 'some local governments, including Tokyo, ban discrimination at work based on sexual identity ... in this group-conscious, relatively conformist society, most gay residents remain in the closet' (Tabuchi, 2013). The Asahi stresses that 'amongst developed countries, Russia and Japan are the only nations where it is said there are absolutely no provisions for same-sex marriage' (Higuchi, 2013: 29). The overwhelming image is of a legal and social system with no anti-discrimination scaffolding in place. The articles, however, each end with an optimistic quote.

'This could prompt Japan to question why it so often ignores or discriminates against minorities,' Hiroko said. 'Mostly we just want people to know that gay people exist for real, and we would like to throw weddings like everyone else' (Tabuchi, 2013). 
'Though we live together there are still many things that work against us in our daily lives so I do hope Japan will change for the better on this,' Hiroko said (Foster, 2013).

Ms Higashi feels 'things are beginning to gradually change' (Higuchi, 2013: 29).

The English language articles (the first two quotes above) state a hope for change in the future quoted from Hiroko. The Japanese article (the third quote above) ends with an expression of change unfolding in the present quoted from Koyuki. Research in critical language studies has identified the ways in which direct quotes from experts may authenticate and valorize a specific viewpoint, and lend independent and neutral support to a newspaper report (Smirnova, 2012: 250; Urbanova, 2012: 51-52; Wodak, 2008: 19; Waugh, 1995: 144). Similarly, quotes may also work to familiarize and reinforce the shared experiences of those closest to an event, topic or social issue. The direct quotes from Hiroko and Koyuki emphasize the personal nature of the event. Although readers are left with a sense that there is much need for change., the emphasise placed on the feelings and thoughts of the couple via the final quotations, strips the event of any political bite. There is no mention of the household registry system (koseki) or marriage laws, or to wedding ceremonies such as Otsuji's, or the support offered by the DPJ in 2007. The event becomes an emotional response to an 'incomplete understanding'.

In sum, the print reports contextualize citations from Koyuki's original microblog alongside quotes from the couple and reference to USA politics of same-sex-marriage. This framework highlight's both the non-legal, and the 'foreign' 'fairytale-like' aspects of the ceremony. These citational practices direct any critique of limits to sexual 
citizenship to the right to pursue a lifestyle through consumption of goods and services (Richardson 2000: 116-123). This recontextualises the issue of same-sex partnership rights and/or marriage equality as removed from a local historical context, and therefore 'new' to Japanese LGBT activism. This aspect is also highlighted in the short news documentary broadcast on $\mathrm{TV}^{\mathrm{xxii}}$ where citational practices common to contemporary audiovisual media regiment the 'official reading' of the program (Park 2009: 557). Visual citations layered onto the screen as impact captioning is manipulated to deflect claims of discrimination and to stress the importance of tolerance by all. These citational practices frame the broadcast and limit claims to sexual citizenship to the prescribed parameters.

\section{Mutual forgiveness - advocating tolerance}

A short news documentary of the TDR wedding was broadcast on the evening TBS (Tokyo Broadcasting System) news program NSuta (the name is taken from a combination of 'news' and 'sutajio [studio]') on 8 March 2013. ${ }^{\text {xiii }}$ It is titled Same-sex marriage: Both in wedding dresses // the anguish and tears before the wedding ceremony// Koyuki (28) and Hiroko (35)'. ${ }^{\text {xiv }}$ The documentary traces the couple as they plan for their TDR wedding in the melodramatic form common to light news documentaries. It includes interviews with both of the women's families and colleagues, and footage of the wedding reception, complete with comments from the guests. The success of the couple's media campaign is reflected in the documentary being aired as a 'featured story' in the early evening news.

The news documentary is pro-active in supporting visibility and acceptance of same-sex couples in the family, at work and in society more generally. It also, paradoxically, 
highlights the issue of erasure by advocating partial social acceptance masked by a veneer of tolerance. Lesbian activists and writers have discussed tolerance as a method of disengaging with social discrimination towards lesbians (Chalmers, 2001; Chalmers, 2002: 1-3, 143-145), and rendering invisible claims to rights (Kakefuda, 1992: 104$\left.119^{\mathrm{xxv}}\right)$. In discussion her critical examination of contemporary discourses of identity and citizenship, Brown understands tolerance as a 'mode of late modern governmentality that iterates the normalcy of the powerful and the deviance of the marginal' (2008: 8). As such, tolerance is an act from the centre to the margin in which those to be tolerated are constituted as 'inferior, deviant, or marginal' (2008: 14). Richardson also notes that tolerance can be a site of contention in relation to the boundaries of claims for sexual citizenship (2000: 122). The notion of tolerance is also invoked in the Nsta news documentary. It is most prominent in a crisis moment and in the crisis resolution which manipulates citational practices common to contemporary audiovisual media, such as narration and text-on-screen, to emphasise the importance of 'forgiveness' in the face of perceived discrimination.

Text-on-screen is prolific in Japanese television. In the documentary, the program logo is displayed at the top left, and the title of this segment is displayed on the upper right of the screen. Impact captioning also appears at the bottom of the screen as speech occurs. Impact captioning is similar to subtitling and closed captions but rather than being a translation of the dialogue into another language or transcription of the audio information, it is a decorative visual representation of the talk-on-screen. Impact captioning never fully represents all of the speech in the sound track. It is citational, but only ever a representation of selected speech. In the editing process, font types, colour, animation, graphics and symbols are applied to the selected sections of speech 
and narration to be layered onto the screen as text. This effectively reinforces directorial intent and shapes how viewers understand, negotiate and engage with the program (Gerow, 2010: 121; Park, 2009: 550, 556-557). Impact captioning therefore, is a metalinguistic commentary that 'shapes the official reading of the media text' (Park, 2009: 557). It provides a window of analysis on the ideological work which informs the final broadcasting package. A microanalysis of impact captioning and corresponding speech appearing in the crisis and resolution scenes illustrates how the notion of tolerance for others in the face of discrimination is highlighted through this complex citational practice. It is one example of how citational practices manipulate discourses about the legitimacy of claims for the right to consume and celebrate same-sex wedding ceremonies, and by extrapolation, equality for same-sex partners in Japan.

\section{Crisis and its resolution projected as text-on-screen}

A major crisis point portrayed in the news documentary occurs midway into the program. The couple has received a message from Hiroko's ex-girlfriend who has accepted the invitation to the ceremony, but asks there be no mention of her past relationship for the sake of her child. Koyuki, shocked at this request from a person attending the couple's ceremony, is reduced to tears as she talks through the issue and the 'realities' (genjitsu) the couple must face with her partner, Hiroko. The narrator repeats Koyuki's words saying that this is 'the social reality thrust upon them before the wedding'. At this critical moment the two decide to visit a friend and advisor. The show breaks to a sponsorship message. The text-on-screen gives just enough information to suggest the crisis is resolved without giving it all away; 'you are creating // society's discrimination', 'beloved teacher's words .... and to the wedding ceremony'. 
When the segment returns, there is a recap of the story so far. The couple are reintroduced as 'a woman and woman love each other-lesbian' (josei to josei ga ai shiau, rezubian); and they are shown walking hand in hand through a park. The request from the ex-girlfriend is cited again in red text superimposed over an image of Hiroko typing on a laptop computer. Music adds to the seriousness of the situation, and we are gradually directed back to an image of both women discussing how to work through this issue. This segues into the mentoring scene.

At the onset of the scene, onshi (respected teacher) and mentor Iwamoto Reiko ${ }^{\mathrm{xxvi}}$ is introduced as a 'kind yet critical sympathizer'. As Koyuki expresses the hurt the episode has caused, sections of the speech unfolding on camera appear as impact captions. Hiroko and Koyuki sit facing their mentor and friend, Iwamoto Reiko. Hiroko listens quietly as Koyuki tries to express her emotions. Selected utterances from the ensuing conversation are also cited in the form of impact captioning (Table 1). Through the citational practices deployed in the post-production editing, therefore, the message that Koyuki herself is compliant in perpetrating discrimination is inscribed visually onto the screen.

\section{Table 1. Text-on-Screen as it unfolds with talk-on-screen}

\begin{tabular}{|l|l|l|}
\hline Speaker & Audible speech [translation] & Caption [translation] $]^{\text {xxvii }}$ \\
\hline Koyuki & soko soko o tsuitekita ka to omoimashita & $\begin{array}{l}\text { soko (kodomo no juken) o tsuitekitaka! tte // } \\
\text { omoimashita }\end{array}$ \\
& I thought [she had to] touch that sensitive & Ithought // [she] poked there (child's entrance \\
\hline
\end{tabular}




\begin{tabular}{|c|c|c|}
\hline & spot there & exams)! \\
\hline & $\begin{array}{l}\text { mōshiwakenai to omotchau n janai desu ka } \\
\text { you feel like sorry don't you right }\end{array}$ & $\begin{array}{l}\text { mōshiwakenai tte omotchau }{ }^{\# x x v i i j a n a i ~ d e s u ~ k a ~} \\
\text { you feel like sorry }{ }^{\#} \text { don't you right }\end{array}$ \\
\hline Iwamoto & $\begin{array}{l}\text { rezubian dakara kimochi warui n janai } \\
\text { desuka, hai, } \\
\text { [we're] sickening because [we're] lesbians, } \\
\text { right, yes }\end{array}$ & 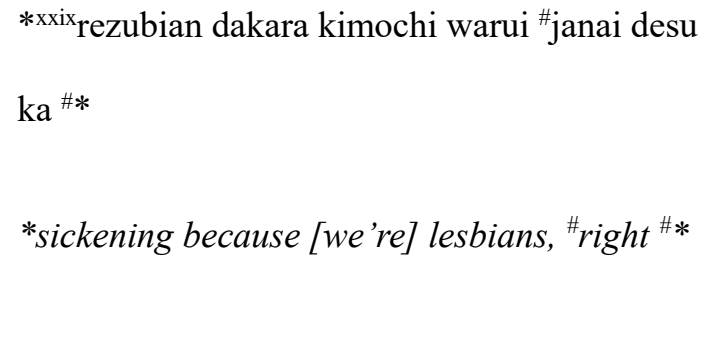 \\
\hline & $\begin{array}{l}\text { anata ga, anata ga seken no anooo fūhyō, } \\
\text { you, society's you, um, rumors, }\end{array}$ & $\begin{array}{l}\text { anata ga seken no fūhyō } \\
\text { you are society's rumours }\end{array}$ \\
\hline & $\begin{array}{l}\text { basshingu } \\
\text { bashing }\end{array}$ & $\begin{array}{l}\text { anata ga seken no fūhyō basshingu } \\
\text { you are society's rumours, bashing }\end{array}$ \\
\hline & $\begin{array}{l}\text { seken no sabetsu } \\
\text { societal discrimination }\end{array}$ & $\begin{array}{l}\text { anata ga seken no fūhyō basshingu // seken } \\
\text { no sabetsu } \\
\text { you are society's rumours, bashing, societal } \\
\text { discrimination }\end{array}$ \\
\hline & $\begin{array}{l}\text { anata ga tsukutte masu } \\
\text { you are creating it }\end{array}$ & $\begin{array}{l}\text { anata ga seken no fūhyō basshingu // seken } \\
\text { no sabetsu anata ga tsukutte imasu } \\
\text { you are, society's rumours, bashing// you are }\end{array}$ \\
\hline
\end{tabular}




\begin{tabular}{|l|l|l|}
\hline \multirow{2}{*}{ Narrator } & sabetsu wa jibun no kokoro no naka ni aru & "sabetsu wa jibun no kokoro no naka ni aru" \\
\cline { 2 - 3 } & discrimination is in your heart & "discrimination is in your heart" \\
\cline { 2 - 3 } & $\begin{array}{l}\text { Iwamoto-san wa kippari to iimashita } \\
\text { Ms Iwamoto frankly said }\end{array}$ & "sabetsu wa jibun no kokoro no naka ni aru" \\
& "discrimination is in your own heart" \\
\hline
\end{tabular}

The representation of the speech unfolding on screen as impact captioning visualises the opinion voiced by the trusted mentor who is also positioned as an understanding ally. A complex chain of citations is mobilised throughout this section where double quotation marks borrowed into contemporary Japanese from English language conventions are used alongside conventional squared quotation marks. Colour, too, is used to mark citational borders. In television broadcasts, differently coloured text is often used to visually demarcate different speakers' words. In this documentary, white edged pink text is used for Koyuki, and white edged yellow text for Hiroko. However, as we can see in the caption for Koyuki's second utterance in Table 1, self-citation is marked by a change from pink to red text with a white edge. This is replicated in the caption that appears as Iwamoto responds (Figure 1a). In both instances, the tagquestion 'you know, right', which urges agreement with the proposition, is represented in a different colour. As viewers we are encouraged to support the statements: 'feel very sorry' and 'lesbians are sickening'. Furthermore, Iwamoto's speech is encased in 
squared quotation marks in the same colour as the first half of the caption (white edged purple text). This serves to both highlight 'you know, right' and marks this opinion as not her own. It is unclear who exactly has said the phrase '[we're] sickening because [we're] lesbians, right, yes' (Table 1; Figure 1a), but the use of colourindicates that the editors intend to visually display it as the words of another speaker. We can only suppose that Koyuki herself has voiced this in a section not shown on screen.

Figure 1. Layering of citations (NSta 8 March 2013)
a) 'sickening because lesbians, right'
b) "society's discrimination, you are"
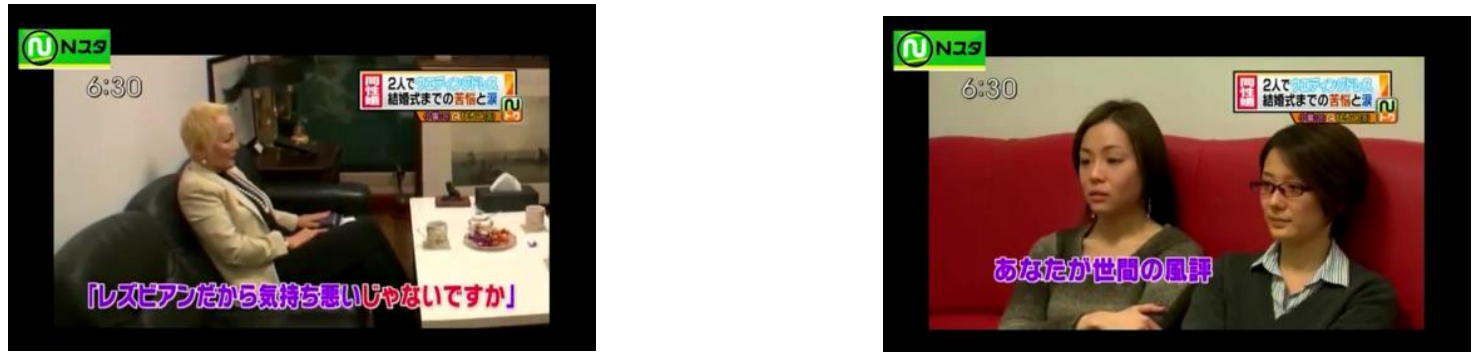

c) you are, society's rumours, bashing//

d) 'discrimination is in your own heart'

you are creating societal discrimination
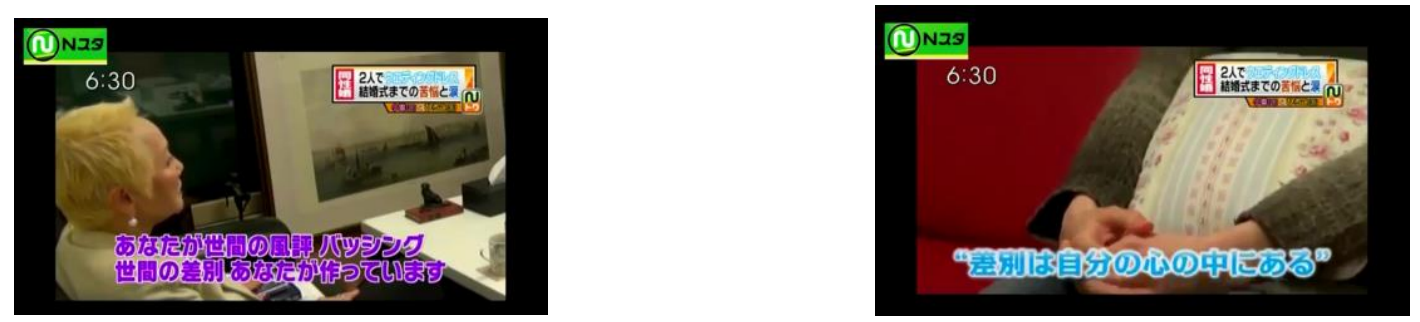

The phrase '(we're) sickening because (we're) lesbians, right, yes', although not overtly attributed to a specific speaker, is the trigger for the forthcoming advice; "you are creating society's discrimination'. Iwamoto pauses, and stumbles to find the correct words (Figure 1b), which are projected into a claim that Koyuki herself is creating the 
discrimination she identifies in the society around her (Figure 1c). The narrator continues by rephrasing Iwamoto's words in the form of a quotation: 'discrimination is in your own heart, Iwamoto frankly said'. The phrase is cited visually as an impact caption in white edged light blue text, and encased with conventional English double quotation marks (Figure 1d). Rather than dismiss the request, Iwamoto urges Koyuki to accept the conflicting emotions of a mother who wants to protect her child, but also wants to wish the couple well. She stresses that is has nothing to do with whether they are lesbian or not as she continues to council; 'you, Koyuki want to be with Hiroko, and Hiroko wants to be with you, isn't that right? it's not a case of whether you are lesbian or not, you know, right'. She offers each a bracelet with a gift card that when read together forms the message 'to coexist' 'is to forgive/tolerate one another' ('kyōsei suru koto to wa' 'tomo ni yurusu koto desu'). Yurusu can be translated as 'to forgive', 'to tolerate' or 'to pardon'. As each woman reads the words on her card, the identical text is projected in white edged yellow text for Hiroko, and white edged pink text for Koyuki. Each is encased with double quotation marks visually marking the phrase as a direct citation. Koyuki is shown crying as Iwamoto repeats 'coexistence means forgiving/tolerating each other'. The message is projected as text-on-screen in its entirety before the narration commences again to reinforce that Iwamoto's message is asking the women to forgive not only each other, or forgive the friend, but also to forgive the society in which they live. The penultimate image from the resolution of crisis scene is of this card and projected text in white edged pink text: 'I want you to be able to "forgive/tolerate"". The melody of "When you wish upon a star' plays gently in the background. The last image of the scene is of Iwamoto hugging Koyuki as her words 'congratulations on your wedding' linger briefly, and the camera rests on Hiroko 
wiping away her tears. The narrator rounds up this emotional segment with the words 'there were no more doubts for the couple'.

The news documentary goes on to show photos of the TDR wedding ceremony. The words 'live together with the public/society (seken/shakai)' are projected onto the screen as the visual changes to footage of the day. The narrator explains that 'the public who had come to the dream world also gave support to the couple who chose to live and coexist with public/society'. The documentary ends with images of cake cutting and speeches in front of friends and family. Once again Koyuki is reduced to tears as Hiroko quotes from the message Iwamoto gave them: 'to coexist is to forgive each other'. The notion that only forgiveness on the part of the lesbian couple will enable coexistence is repeated cited both audibly and visually. In this configuration, manipulation of opinions voiced in the documentary produces repeated reiterations of the same phrase. This citational practice reinforces the dominant ideological framework that societal tolerance for the women's relationship pivots on the women themselves forgiving societal discrimination.

The broadcast is a major breakthrough in lesbian visibility, and contributes greatly to promoting awareness not only of the hurdles faced by same-sex partners. It also shows the support the couple receive from family, work colleagues and friends, and the joy they experience. However, the complex citational practices that have been embedded into the broadcast package in post-production emphasize that there are limits to visibility and claims for understanding. The use of direct and indirect quotations reworks the homophobia voiced in the crisis scene back into the personal discourse of the couple. This effectively excludes it from the realms of open public discourses and recontextualizes it as a private struggle towards mutual coexistence. Furthermore, the 
image of US president Obama voicing support for marriage equality which is spliced into the documentary places the issue within a global context, but at the same time marks as 'foreign' the concept of same-sex marriage. The use of text as metalinguistic commentary, therefore, is carefully manipulated to display an 'official reading' (Park, 2009: 557) of the importance of tolerance, and to distance discourses of same-sex marriage from the local context. The layering of citations shapes dicsourses of sexual citizenship by marking the local context as one inflected with tolerance for the consumption of wedding packages by same-sex couples within Japan, but distanced from claims to marriage equality.

Contemporary Japanese mainstream newspapers have dutifully reported the passing of same-sex marriage laws in New Zealand, France, the USA and Ireland. They have repeated and translated influential leaders', such as USA president Barack Obama's support for marriage between partners of the same sex/gender. When placed in this context, the complexity of the network of texts surrounding same-sex marriage issues in Japan becomes more acutely defined. In the case of the Tokyo Disney Resort wedding, by not referencing previous calls for marriage equality and not invoking the support offered by domestic politicians (that is, from the 2007 reporting), the issue of same-sex partnerships is created anew within a fairytale context. The contours of sexual citizenship are shifted to exclude full engagement with Japanese legal and/or familial constraints. Similarly, by not contextualizing the ceremony within a domestic history of discussion, dissent and activism, marriage equality itself is presented as an issue 'new' to Japan and yet to be discussed.

\section{Conclusion}


Contemporary studies of sexual citizenship have identified the ways in which claims to civil, political and social rights and responsibilities (Bell and Binnie, 2000: 1-3), pivot upon legal, social and cultural discourses of racialized, gendered, sexed and able-bodied individuals. The intersection of state and market (Evans, 1993: 8), the commodification of sexuality, and the marketization of rights (Bell and Binnie, 2000: 7) which overwhelmingly minimalize economic disparities, it is argued, have been propelled within neoliberal discourses of self-determination and choice. Debates around the 'rights, obligations, recognitions and respect around those most intimate spheres of life' (Plummer, 2001: 238) have been played out in both public and private. The issue of same-sex partnership rights and marriage equality is one such debate. Media representations of claims to such rights impact on the ways in which sexual citizenship is understood and defined in local contexts. Citational practices not only transport not news and opinions, but frame these within the ideological boundaries of the medium.

In the Japanese context, legal marriage can only be understood in relation to the family registry system. De facto relationships outside of this system experience limited recognition by the state and other social institutions. Although newspaper reporting about women in same-sex marriage-like arrangements can be traced back as far as the late nineteenth century, it is only since the 'gay boom' of the 1990s that articles in mainstream publications and books by commercial presses have referenced the issues of same-sex partnerships rights. Columns and articles about partnership rights have also consistently appeared in LBGT community publications.

Since the mid-2000s, two same-sex weddings in Japan have garnered the attention of both the LGBT and mainstream press. Complex citational practices common to print, audiovisual and social media texts have been used to recontextualise these events in 
media reporting. In the 2007 case, domestic support from well-known politicians is mitigated by citational practices that clearly mark the wedding as devoid of legal standing. Increased media visibility for lesbian women and same-sex partnership rights is also mitigated by techniques that protect the identity of individuals unable to appear openly on video. The 2013 reports situate the struggle to wear the clothing of choice in one's purchased wedding ceremony package, in the context of marriage equality trends internationally. However, the source of initial trouble is repeatedly cited as 'incomplete understanding' thereby downplaying any claims of possible discrimination. As I have shown in a microanalysis of text edited into a news documentary, the importance of 'mutual coexistence' based on 'forgiveness/tolerance' is emphasised to counter claims of perceived homophobia. Furthermore, the ceremony is situated within a 'fairytale' world facilitated by a 'foreign' multinational corporation selling 'dreams'.

Critical engagement with the family registry system (koseki) which defines familial relations and the contours of nationality and maps out one's responsibilities and rights in relation to social welfare, taxation, inheritance and partner care is minimalized through the use of complex citational practices. Hence, work by queer activists, such as the 'anti-marriage' contingent who marched in the $7^{\text {th }}$ Tokyo Pride Parade in 2010, remain hidden. Similarly, scholarly critiques (such as Horie, 2010) and calls for alternatives in the work of groups such as Partnership Law Japan (Tokubetsu-haigūshahō Zenkoku Nettowāku) or the National Sexual Minority Support Network for a Mutual Society (Kyōseishakai o tsukuru Sekushuaru Mainoriti Shien Zenkoku Nettowāku) are not widely disseminated. By not citing a domestic history of discussion, dissent and activism around same-sex partnership rights, something which has continued from at least the 1990s, marriage equality itself is presented as an issue 'new' to Japan. The 
process of 'othering' issues of sexual citizenship is linked to a cyclical process since the 1950s wherein representations of queerness are posited as 'new' forms of being in Japan. Claims to sexual rights are recontextualized as belonging elsewhere and partial social acceptance is mitigated by ideologies of tolerance. Public media discourse surrounding sexual citizenship thereby projects it into a non-domestic, non-specific future time.

\section{References}

Asahi Shimbun-sha (ed.) (1997) Ren'ai to Kekkon: Meiji/Taishō [Love and marriage: Meiji and Taisho]. Tokyo: Asahi Shimbun-sha.

Bakhtin M M (1986) Speech Genres and Other Late Essays. Austin, University of Texas Press.

Bell D and Binnie J (2000) The Sexual Citizen: Queer Theory and Beyond. Cambridge: Polity Press.

Calsamiglia H and Ferrero C L (2003) Role and Position of Scientific Voices: Reported Speech in the Media. Discourse Studies 5 (2): 147-173.

Chalmers S (2001) Tolerance, Form and Female Dis-ease: The Pathologisation of Lesbian Sexuality in Japanese Society. Intersections: Gender, History and Culture in the Asian Context 6 (August). Available at: http://intersections.anu.edu.au/issue6/chalmers.html (accessed 20 December 2012).

Chalmers S (2002) Emerging Lesbian Voices from Japan. Richmond: RoutledgeCurzon. 
Chapman D and Krogness KJ (eds) (2014) Japan's household registration system and citizenship: koseki, identification and documentation. Oxon: Routledge.

Cossman B (2007) Sexual citizens: The legal and cultural regulation of sex and belonging. Stanford: Stanford University Press.

Brown, W (2008) Regulating Aversion: Tolerance in the Age of Identity and Empire. Princeton: Princeton University Press.Doi K (2012) (Watashi no shimbun hihyō) Seiteki shōsūsha no hōdō Asahi Shimbun Shimenshingikai iin/ Doi Kanae-san [(My newspaper critique) Reporting on sexual minorities Asahi Newspaper's Press Advisory Council-Ms Kanae Doi]. Asahi Shimbun, 14 February.

Dōsei kekkon, Mikkī Mausu mo shiji Tōkyō Dizuni rizōto [Same-sex wedding, backed by Mickey Mouse too Tokyo Disney Resort], (2012) AFP-BB News (15 May). Available at: http://www.afpbb.com/article/life-culture/life/2878096/8945995 (accessed 1 February 2013).

Evans, David T (1993) Sexual citizenship: the material construction of sexualities. London; New York: Routledge.

Fairclough N, Pardoe S and Szersynski B (2010) Critical Discourse analysis and citizenship. In: N Fairclough (ed) Critical Discourse Analysis: The Critical Study of Language. Harlow: Pearson Education.

Foster S (2013) Tokyo Disneyland Hosts Gay White Wedding. ITN (6 March). Available at: http://www.itn.co.uk/World/70395/tokyo-disneyland-hosts-gaywhite-wedding (accessed 1 February 2013).

Gay in Japan. News Week Japan, 25 January 2006. 
Gay Renaissance. Crea, December, 1991.

Gerow A (2010) Kind Participation: Postmodern Consumption and Capital with Japan's Telop TV. In: M Yoshimoto, A Tsai and J Choi (eds) Television, Japan and Globalization. Ann Arbor: Center for Japanese Studies, The University of Michigan.

Goffman E (1981) Forms of Talk. Philadelphia: University of Pennsylvania Press.

Goldstein-Gidoni O (1997) Packaged Japaneseness: weddings, business and brides. Honolulu: University of Hawai'i Press.

Goodman, J E, Tomlinson M and Richland J B (2014) Citational Practices: Knowledge, Personhood, and Subjectivity. Annual Review of Anthropology 43 (1): 449-63.

Higashi K (2012a) Watashi-tachi dōsei kappuru mo ‘Disney Royal Wedding’ ga dekimasuka? [Can we same-sex partners have a 'Disney Royal Wedding', too?]. In: @koyuki higashi. Available at: https://twitter.com/koyuki_higashi/status/183489499542724608 (accessed 1 February 2013).

Higashi K (2012b) Tōkyō Dizunī Rezōto de, uedingu doresu x uedingu doresu de kekkon shiki ga dekimasu! (We can have a wedding dress $\mathrm{x}$ wedding dress wedding ceremony, at Tokyo Disney Resort). In: koyuki's blog. Available at: http://koyuki-higashi.tumblr.com/post/20347911645/x (accessed 1 February 2013).

Higashi K (2012c) Dizunī dōsei kekkon shiki OK ni tsui, sankyū messēji o Mikki ni todokemashita! (Delivered a thank you message to Mickey at last for the OK for a 
Disney same-sex wedding ceremony). In: koyuki's blog. Available at: http://koyuki-higashi.tumblr.com/post/22633544455/ok (accessed 1 February 2013).

Higashi K (2013) Dai 11-kai Kyōsei suru koto wa tomo ni yurusu koto (No. 11 To coexist is to forgive one another). In: 2Chopo LGBT no tame no Communitī saito (2Chopo: A community site for LGBT). Available at: http://www.2chopo.com/article/detail?id=498 (accessed 10 September 2015).

Higuchi D (2013) Watashi rashiku ikiru Josei dōshi, doresu sugata de kekkonshiki reinbō Kanazawa no daihyō Higashi-san [Living true to oneself Two women, Weddding ceremony in dresses, Rainbow Kanazawa Representative Ms Higashi], Asahi Shimbun (Ishikawa), 7 April, 29.

Horie Y (2010) Dōseikan no ‘kon'in' ni kansuru hihanteki kōsatsu: Nihon no shakai seido no bunmyaku kara [Critical thoughts relating to same-sex 'marriage': In the context of Japan's social system]. Shakai Shisutemu Kenkyū 21: 37-57.

Hosogai S (1997) ‘Post-kekkon' jidai ni pātonāshippu wa dō kawaru [In a 'postmarriage' era how will partnerships change?]. Cosmopolitan, April, 106-109.

Ishida H and Murakami T (2006) The Process of Divergence between 'Men who Love Men' and 'Feminised Men' in Postwar Japanese Media. Intersections: Gender, History and Culture in the Asian Context 12 (January) Available at: http://intersections.anu.edu.au/issue12/ishida.html (accessed 20 December 2012).

Itō S (1993) Otoko futari gurashi: Boku no gei puraido sengen [Two men living together: My gay pride manifesto]. Tokyo: Tarō Jirō-Sha. 
Izumo M (1993) Manaita no ue no koi [Love upon the chopping board]. Tokyo: JICC shuppan-kyoku.

Izumo M and Maree C (2000) Love upon the chopping board. North Melbourne: Spinifex Press.

Josei dōshi futari eien no ai chikau Naka-ku de "kekkonshiki"” (2007) [Two women together Promise everlasting love-'Wedding' in Naka-ku]. Asahi Shimbun, 4 June.

Josei dōshi, ueddingu doresu de kekkonshiki Dizunī Shī de yume o kanau [Woman and woman, wedding ceremony in dresses. Wishes come true at Disney Sea]. Asahi Shimbun Digital, 7 April 2013. Available at: http://asahi.national.com/national/update/0407/OSK20130406139.html (accessed 24 April, 2013).

Kachgal T (2004) "Look at The Real World. There's always a gay teen on there": Sexual citizenship and youth-targeted reality television. Feminist Media Studies 4: 361364.

Kahlina, K (2015) Local Histories, European LGBT Designs: Sexual Citizenship, Nationalism, and 'Europeanisation' in Post-Yugoslav Croatia and Serbia. Women's Studies International Forum 49: 73-84.

Kakefuda H (1992) 'Rezubian de aru' to iu koto [On “being lesbian”]. Tokyo: Kawade shobō.

Keiser Y (2007) Otsuji Kanako-shi, Kokusei senkyo shutsuba kettei kaiken [Ms Otsuji Kanako, press conference announcing decision to run for national office]. Tokyo 
Wrestling, 15 May. Available at:

http://www.tokyowrestling.com/articles/2007/05/post_10.html. Accessed 1 February 2013).

Lesbian politician in Japan gets hitched. (2007) PinkNews.co.uk (5 June). Available at: http://www.pinknews.co.uk/2007/06/05/lesbian-politician-in-japan-gets-hitched/ (accessed 1 February 2013).

Maree C (2013) Sexual citizenship at the intersections of patriarchy and heternormativity_-same-sex partnerships and the koseki. In: Chapman D and Krogness KJ (eds) Citizenship and Japan's Household Registration System: The State and Social Control. Oxon: Routledge, pp. 187-202.

Maree C (2014) Queer Women's Culture and History in Japan. In McLelland M and Mackie V (eds) Routledge Handbook of Sexuality Studies in East Asia. Oxon: Routledge, pp. 230-243.

McLelland M and Dasgupta R (eds) (2005) Genders, transgenders and sexualities in Japan. London: Routledge.

McLelland M (2005) Queer Japan from the Pacific war to the internet age. Lanham, Md.: Rowman \& Littlefield.

Nippon Television Network. News Zero, 11 July 2007.

Onna dōshi no fūfu [A female couple]. Yomiuri Shimbun. 27 January 1910, 3.

Otsuji K (2005) Kamingu Auto: Jibun rashisa o mitsukeru tabi [Coming Out: A Journey to Find My True Self]. Tokyo: Kōdansha. 
Ōtsuka T (1995) Ni-chōme kara Uroko [Be awakened to 2-chōme]. Tokyo: Shūeisha.

Park J S-Y (2009) Regimenting languages on Korean television: subtitles and institutional authority. Text \& Talk (29): 547-570.

Plummer K (2001) The Square of Intimate Citizenship: Some Preliminary Proposals. Citizenship Studies 5(3): 237-253.

Porfido G (2009) Queering the Small Screen: Homosexuality and Televisual Citizenship in Spectacular Societies. Sexualities 12(2): 161-179.

Queer Studies Henshūiinkai (eds) (1996) Queer Studies '96. Tokyo: Nanatsumori Shokan.

Richardson D (2000) Constructing sexual citizenship: theorizing sexual rights. Critical Social Policy (20): 105-135.

Sawabe H (2011) Unions and disunions: three early lesbian couples. In: K FujimuraFanselow (ed), Transforming Japan: how feminism and diversity are making a difference. The Feminist Press at CUNY, New York.

Seidman Steven (2001) From Identity to Queer Politics: Shifts in Normative Heterosexuality and the Meaning of Citizenship. Citizenship Studies 5(3): 321328.

Smirnova A (2012) Argumentative use of reported speech in British newspaper discourse. Text and Talk 32 (2): 235-253.

Sugiura I (2006) Lesbian Discourses in Mainstream Magazines of Post-War Japan: Is Onabe Distinct from Rezubian? Journal of Lesbian Studies. 10(3/4): 127-144. 
Tabuchi H (2013) Gay Wedding Is Embraced by Disney in Tokyo. The New York Times, 5 March. Available at: http://www.nytimes.com/2013/03/05/world/asia/socialmedia-embrace-same-sex-wedding-at-tokyo-disneyland.html?_r=0 (accessed 1 February 2013).

Urbanova Z (2012) Direct and free direct forms of representation in the discourse of newspaper reports: Less frequent phenomena. Brno Studies in English. 38(1): 3954.

van Leeuwen, Theo. 'Linguistic Representation: The Recontextualization of Participants, Activities and Reactions,' PhD Thesis, University of Sydney, 1993.

Waugh L (1995) Reported speech in journalistic discourse: The relation of function and text. Text 5 (1): 129-173.

Wockner R (2007) Asia/Pacific: Lesbian Japanese Politician Marries. Just Out 24: 21.

Wodak R (2008) Introduction: Discourse Studies - Important Concepts and Terms. In: Wodak R and Krzyzanowski M (eds) Qualitative discourse analysis in the social sciences. Basingstoke: Palgrave Macmillan.

Wodak R (2010) The Glocalization of Politics in Television: Fiction or Reality? European Journal of Cultural Studies 13 (1): 43-62.

Yamamoto R (2012) Tokyo Disneyland offers the ultimate fairy-tale wedding.The Asahi Shimbun, 5 June. Available at: http://ajw.asahi.com/article/cool_japan/style/ AJ201206050021 (accessed 25 June 2014). 
Yamashita A (2007) Otsuji Kanako zen Ōsakafugi, dōsei pātonā to ueddingu [Ex-Osaka councillor Otsuji Kanako, Wedding with same-sex partner]. Gay Japan News, 5 June. Available at: http://gayjapannews.com/news2007/news109.htm (accessed 1 February 2013).

Claire Maree is Senior Lecturer in Japanese at the Asia Institute, University of Melbourne. Her current research project is 'Writing Identity onto the Screen: Subtitles and captions in Japanese media' (ARC DP150102964). Major publications include 'Onē-kotoba' Ron (On 'Onē-kotoba [language of queens]')(Seidosha, 2013); Hatsuwasha no gengo sotoratejī toshite no negoshiēshon kōi (Negotiation as a Linguistic Strategy of Speakers) (Hituzi Shobo, 2007). She has published chapters in collected volumes on Japanese language and gender, pragmatics, and queer studies. She contributes articles to journals such as The Asia-Pacific Journal, Media International Australia, Nihon Joseigakkai-shi, Journal of Lesbian Studies, Women's Studies, Intersections and Gendai Shisō.

\footnotetext{
${ }^{\mathrm{i}}$ In this paper I follow Japanese conventions for names where the family name is followed by the given name.
}

ii Otsuji Kanako (1974- ) is a LGBT activist, former member of the Osaka Municipal Government (2003-2007), and former member of the House of Councillors of the National Diet (2013).

iii Higashi Koyuki (1985- ) is an LGBT activist and writer. 
${ }^{\text {iv }}$ Masuhara Hiroko (1977- ) is an LGBT activist and writer.

${ }^{v}$ Although Hiroko has since published under her full name, in this paper I will refer to them both by their first names, Koyuki and Hiroko, to reflect reporting of the event at the time.

${ }^{\text {vi }}$ The current law requires that the individual must i) be over 20 years of age, ii) be unmarried, iii) not have children who are minors, iv) have no reproductive functioning, v) have the outward genital appearance of that sex.

vii One (literally “older sister" or "senior woman") is a term used within the Japanese queer community to refer to effeminately queer men. One-kyara (literally onē character) is the generic name given to MTF transgender and gender queer male TV personalities.

viii Note that the earlier article uses the word josei, and the later onna, both terms mean "female/woman".

ix The koseki is the Japanese family registry. Members on the same register, or those who can demonstrate familiar ties via the registry, are deemed legal family members. Only Japanese nationals can be entered onto the family register, non-Japanese spouse are entered as a note in the margins of the main entry. For a recent edited volume on the koseki see Chapman D and Krogness KJ (2014).

x The Supreme Court upheld the law which requires legally married couples to hold the same surname as recently as December, 2015.

${ }^{x i}$ Adult adoption allows a person of younger age to be registered on the older person's 
family register thereby constituting a familial relationship. It has been used traditionally to ensure familial continuity. A legal family relationship allows access to inheritance rights, dependency taxation benefits, health insurance and so on. A well-known case of same-sex adult adoption is famous popular author Yoshiya Nobuko's (1896-1973) adoption of her long-term partner Monma Chio (1897-1996) (Sawabe, 2011).

xii The Setagaya and Shibuya wards of Tokyo announced initiatives in 2015.

xiii The 'gay boom' period of Japanese queer history is marked by popular media interest in gay men's culture and community which is usually traced to a special issue of glossy magazine Crea titled the 'Gay Renaissance' (1991). Featuring interviews, exposés and fashion/lifestyle advice, it also marks the beginnings of a fledgling lifestyle industry wherein queer personalities have been brought to the mainstream as symbols of desirable consumable lifestyles.

${ }^{\text {xiv }}$ Otsuji took up a seat in the House of Councillors vacated due to a resignation. She was the first openly lesbian politician in the National Diet in Japan.

${ }^{\mathrm{xv}}$ All translations are mine unless indicated otherwise.

xvi 'Virgin road' is the Japanese-English name given to the path a bride walks from the entrance to the altar of a church or, in other words, walking down the aisle.

xvii The broadcast was also posted to YouTube, May 2009, adding another element to the chain of citations linked to this event.

xviii Text-on-screen is prolific in Japanese television broadcasts, and will be further analysed below. 
${ }^{\text {xix }}$ Circa September 2015, Ozawa Ichirō is joint president of The People's Life Party and Taro Yamamoto and Friends.

${ }^{\mathrm{xx}}$ News of 'Disney's Royal Dream Wedding Package' was reported in the English and Japanese language press. The Asahi Shimbun online cites the package price in 2012 as 7.5 million yen (US\$94, 000) (Yamamoto, 2012).

${ }^{\text {xxi }}$ For a discussion of packaged weddings in Japan, see Goldstein-Gidoni (1997).

xxii A copy of this was also posted online adding another segment to the citational chains.

xxiii A week later, on 15 March 2013, a slightly edited recording was posted to YouTube adding another segment to the citational chain of events unfolding around the TDR wedding.

xxiv // denotes a line break between different lines of text superimposed on screen.

${ }^{\mathrm{xxv}}$ Kakefuda notes that on the whole society is more tolerant (kan'yō) towards two women together than two men. This makes prejudices against lesbians less visible as people 'pretend not to see' (mite minai furi) (Kakefuda, 2000: 104).

${ }^{x x v i}$ Iwamoto is a counsellor with the Japan Institute for Psychotherapy, and a representative for A Course in Miracles (ACIM), a program in spiritual counselling. Higashi Koyuki's interview with Iwamoto on what yurusu (forgiveness/tolerance) means appears as her 11th column on the 2Chopo LGBT community site (Higashi, 2013).

xxvii The screen is framed by the program mascot [circular emblem and text 'Nsta'] on 
the upper left, and segment mascot 'NToku (an abbreviation of Nyūsu Tokushū (News Feature)' with subtitle: 'Dōseikon Futari de Ueddingu Doresu //Kekkonshiki made no kunō to namida// Koyuki (28) to Hiroko (35)' (Same-sex marriage: Both in wedding dresses // Anguish and tears until the wedding ceremony// Koyuki (28) and Hiroko (35) on the upper right (Figure 1).

xxviii \# indicates a change in text colour.

xxix $* *$ indicates the beginning and end point of text enclosed with conventional Japanese squared quotation marks. 